\title{
INFLATION, BI 7 DAYS REPO RATE, AND JAKARTA COMPOSITE INDEX ON NET ASSET VALUE OF SHARIA MUTUAL FUND
}

\author{
Happy Irma Riyanti Prabowo ${ }^{a}$ \\ Nana Diana ${ }^{b}$ \\ ${ }^{a, b}$ Department of Accounting, Faculty of Economics and Business, Universitas Singaperbangsa \\ Karawang \\ Email: 1710631030007@student.unsika.ac.id ${ }^{\text {a }}$, nanadiana.ekonomi@gmail.com ${ }^{b}$
}

ARTICLE HISTORY

Received:

24 January 2021

Revised

8 April 2021

Accepted:

31 May 2021

Online available:

30 June 2021

\section{Keywords:}

Net Asset Value, Sharia Mutual Fund, Inflation, BI7DRR, Jakarta Composite Index.

*Correspondence:

Name:

Happy Irma Riyanti Prabowo

E-mail:

1710631030007@student unsika.ac.id

\begin{abstract}
This research purposed to examine the effect of inflation, $\mathrm{BI} 7$ Days Repo Rate (BI7DRR), and Jakarta Composite Index on the net asset value of sharia mutual fund. The method used is the descriptive and derivative method with a quantitative approach, with multiple linear regression analysis to find the relationship between the variables. This study uses purposive sampling as the sampling technique, which is the sharia mutual fund registered in the Financial Services Authority of Indonesia. This research observed the variables in the period of 2016 to 2020 with monthly time series from secondary data. The findings result that partially, inflation has significant effect with negative direction on the net asset value of sharia mutual fund, while the BI7DRR and Jakarta Composite Index has insiginificant impact on the net asset value of sharia mutual fund. This result shows the investment behavior by investor where the inflation rate becomes a consideration whether to put their fund in investment, especially sharia mutual fund or more concern on their consumption. On the other side, the value of BI7DRR and the Jakarta Composite Index does not become investor's consideration to investing in sharia mutual fund. For simultaneous effect, inflation, BI7DRR, and Jakarta Composite Index have a significant effect on the net asset value of sharia mutual fund for $66 \%$, which shows that the combined economic situation consisting of these factors can affect the movement of the net asset value of sharia mutual fund with a possibility of $66 \%$, while $34 \%$ of the possibility left can be affected by variables outside this research.
\end{abstract}

\section{INTRODUCTION}

Nowadays, the number of citizens who know investment increases, especially with all the conveniences and sophistication of technology that reach all levels of demographics, the range of ages, and in any regional conditions. Most people used to put their funds in savings before the investment was getting so popular. However, 
with the development of the world business economy and technology nowadays, many people have set aside some of their fund to buy stocks, bonds, or fine gold, promising more returns in the future (Mastura et al., 2020). The return obtained is one of the motives that increase people's desire to invest. Investment instruments also divided into many varieties: low-risk with low returns and high rish with high returns. The example for each instrument is deposits and bonds and to capital market products.

As an investment choice that provides a fairly high return, the capital market has become popular and exciting to the public. Study of Kasmir (2014) stated that sellers in the capital market are companies that need capital (issuers), so they do business in order to sell securities on the capital market, while buyers (investors) are parties who want to buy capital in companies that they think are profitable. The capital market law Number 8 of 1995 defines the capital market as activities related to public offering and securities trading, and public companies related to securities as well as institutions and professions related to securities. A capital market is a place related to public offering and securities trading activities that trade various long-term financial instruments such as bonds, stocks, mutual funds, and other instruments (Lailiyah et al., 2016). A capital market is also a place where the capital of a business entity is traded, where the business entity will use the funds raised for business continuity, and investors will benefit from the difference in value or the agreed profit sharing of the business entity. The capital market provides an alternative for investors to invest in both short and long term, which basically causes investors to be interested in investing their funds (Nisa, 2017).

Investing in the capital market is influenced by people's interest and motivation in improving and meeting financial goals. Several things may affect people to invest their fund in the capital market, such as understanding how to invest, the capital to be invested is affordable, and motivation to show their existence (Nisa, 2017). Another factor that can increase people's investment power is the need to invest itself, but this is limited by the financial capacity of the individual, where if this financial capacity is deemed sufficient, it will indirectly affect the fulfillment of substantial needs. According to Saputra (2018), the need to invest is carried out by someone when their substantial needs have been met, such as psychological needs and security needs. Someone who has funds that exceed their substantial needs will think about using these funds. If the remaining funds owned by the individual cannot be saved enough, then the investment power will decrease. Another thing that limits investment power is the knowledge of investment itself. Mastura et al. (2020) explained that some of the understanding of investment knowledge are understanding how business/investment objectives and business work, the risk of return obtained, choosing companies that have strong business fundamentals, investing time, allocating portfolios efficiently, and learning about both technical and 
fundamental stock analysis. Financial ability and knowledge are very important to start investing, especially novice investors, to avoid confusion and even losses due to a lack of understanding of how the capital market works and what risks can arise at any time. Sufficient knowledge, experience, and business instincts are needed to analyze which effects will be purchased in investing in the capital market (Mastura et al., 2020).

Answering the obstacles from the lack of discretionary income and public investment knowledge, mutual funds are a solution to these worries. Like other capital market instruments, mutual funds raise funds from investors, which investors will later benefit from the invested capital. The difference is, in mutual funds, the funds invested by investors will be managed by the investment manager to be reinvested into other investment instruments.

According to the Capital Market Law Number 8 of 1995, Article 1 paragraph 27 defines mutual funds as a vehicle that is used to raise funds from the investor community to be invested in securities portfolios by investment managers. The existence of the investment manager will make the investors who are still lack understanding and knowledge about the capital market can reduce their worries about choosing and buying good securities and the threat of too large a loss.

A qualified and professional investment manager will reinvest investor funds into the portfolio in accordance with their policies and considerations. Minimizing risk is one of the considerations for investors in investing, and this is fulfilled in mutual fund instruments because they are managed professionally by experienced investment managers. Therefore, investors do not have to participate in analyzing investment portfolios (Febriani, 2014). It provides an easy choice for investors, especially for beginners. In addition, the advantage of mutual funds is that the capital required is not too high, so mutual funds are very suitable for people with little capital but have the desire to invest.

In Indonesia, which is Muslims dominate, the availability of mutual funds whose mechanisms and regulations do not contravene to Islamic religion principles are very needed, considering the religious principles must be applied in everyday life, including in terms of investing. Rules related to Indonesian Islamic or Sharia capital market are issued by the Financial Service Authority/Otoritas Jasa Keuangan (OJK) in the form of regulations and the government directly in the form of laws and supporting regulations. Sharia mutual funds, according to the regulation of Otoritas Jasa Keuangan Number 19/POJK.04/2015, is a mutual fund as defined in the Law on Capital Market and its implementing regulations whose management does not conflict with the sharia principles in the capital market. These principles of sharia are derived primarily from the Al-Quran and Al-Hadith, which scholars interpret as the science of figh. The issuance of Fatwa Number 20/DSN-MUI/IV/2001 also serves as a valid statement that investing in sharia mutual funds is halal and permissible for Muslims. Halal which does not violate the principles of sharia, among the 
transactions contained therein do not contain elements such as maisir, gharar, usury, falsehood, bai'al-ma'dum, ikhtikar, and taghrir. It is said to be halal, if the party issuing the investment instrument does not do business that is contrary to Islamic principles, such as the example of business activities above, not making usury or interest in money, while in terms of regulations, treatment and profit sharing are the same as conventional mutual funds (Qomariah et al., 2016). One thing that distinguishes conventional sharia mutual funds is the contract. This sharia contract can include a cooperation contract (musyarokah), lease (ijarah), and a profit sharing contract (mudharabah) in the mechanism of sharia mutual fund activities. Sharia mutual funds are generally managed based on the mudharabah principle, where the investment manager and custodian bank act as the manager (mudharib) and the investor the owner of the fund (shahibul maal) (Bakrie, 2019).

Trading mechanisms and halal mutual funds were increasingly attracted public interest and growing rapidly until this moment and it is interesting to discuss its development. To evaluate mutual fund performance can be seen from the net asset value per unit participation. Net asset value is basically historical data containing assets after deducting from liabilities (Ulinnuha et al., 2014). The amount of net asset value can fluctuate every day, depending on changes in the value of securities and portfolios. An increase in net asset value indicates an increase in shareholder investment value per unit of participation. Likewise, on the contrary, decreasing means that the investment value of the unit holder is reduced (Rachman \& Mawardi, 2015).

Factors that can affect the net asset value of this mutual fund include a country's macroeconomic factors, such as inflation, bank interest rates, and Jakarta composite index. High inflation will increase the price of goods, consequently it will reduce purchasing power and indirectly affect the capital market (Bakrie, 2019). The increased $\mathrm{BI}$ rate will indirectly provide a stimulus to the public to save in banking, people think that increased interest in banks will increase their profits when they choose to save in banking (Prasetyo \& Widiyanto, 2019), which of these will affect the decline in people's purchasing power in sharia mutual funds, so that the profits from sharia mutual funds also decrease. Meanwhile, the Jakarta Composite Index could also have an effect on mutual funds performance.

Hermawan and Wiagustini (2016) states that the factors that influence mutual fund performance are the Jakarta Composite Index and interest rates. The fluctuation of the Jakarta Composite Index value greatly affects the fluctuation of net asset value in mutual funds, especially equity funds, because the funds collected from the public for equity funds are mostly allocated to stocks. Kasyfurrohman (2012) shows that Jakarta Composite Index negatively affect the net asset value of sharia mutual funds. This fact is in accordance with the concept that if the Jakarta Composite Index has increased, reflecting the company's performance in the conventional capital market 
increases so that it has the potential to earn higher income. Increased company revenue will cause an increase in return for shareholders. Therefore, people will tend to invest their funds in mutual funds with the hope of getting a greater return and reducing risk. This act is because a competent professional in this field manages their investment so that the net asset value of mutual funds will also increase.

This research examines the accuracy of the previous research results by using the period of 2016 to 2020 as the newest data, so this research can find the updated result and show the relationship between the variables in the long term.

\section{LITERATURE REVIEW}

\section{Sharia Accounting}

Sharia accounting is an activity of identification, clarification and reporting through making economic decisions based on the principles of sharia contracts, namely not containing zhulum (injustice), usury, maysir (gambling), gharar (fraud), haram, and dangerous goods (Khaddafi et al., 2017). Mulawarman et al. (2011) state that Islamic accounting is a step to describe modern accounting on the form and requirements of humanistic values. The purpose of implementing Islamic accounting is to develop a business civilization with a humanistic, emancipatory, transcendental and theological perspective. Sharia accounting is defined as the process of recording, classifying, and summarizing financial transactions measured in units of money and reporting the results based on sharia principles.

\section{Sharia Mutual Fund}

According to Wiradiyasa (2016), to be able to see the development of sharia mutual funds can be presented with the development of the net asset value of Sharia mutual funds from year to year. So, net asset value is one of the benchmarks in monitoring the development of a mutual fund. Net asset value is the fair price of a mutual fund portfolio after deducting operational costs then divided by the number of shares/units that have been outstanding (owned by investors) at that time. According to Yazir and Suhardi (2014), net asset value is an indicator in determining the buying price and selling price of each mutual fund participation unit. Changes in net asset value can be used as an indicator of a mutual fund's performance whether its value is positive or negative.

\section{Inflation}

On its website, Bank Indonesia (2020) explains that inflation is the tendency of prices to increase generally and continuously. The Central Bureau of Statistics of Indonesia/Badan Pusat Statistik (BPS) (2021) also provides information on its website that if the price of domestic goods and services increases, then inflation will increase. The increase in the prices of these goods and services causes a decrease in the value of money. Thus, inflation also can be interpreted as a decrease within the value of 
money against the worth of products and services generally. In measuring the inflation rate, the indicator used is the Consumer Price Index (CPI). The index uses to calculate the average change in the price of a package of goods and services consumed by a household over a certain period of time. Since January 2020, inflation measurement in Indonesia uses the $2018 \mathrm{CPI}$ base year $=100$. The research result of Wirman (2020) found that inflation has a significant positive effect on the net asset value of sharia mutual fund. Meanwhile, Prasetyo and Widiyanto (2019) found that inflation has no effect on the net asset value of sharia mutual funds.

\section{BI7DRR (BI 7 Days Repo Rate)}

Bank Indonesia 7 Days Repo Rate (BI7DRR) is the policy interest rate implemented by Bank Indonesia since 19 August 2016 replacing the $\mathrm{BI}$ rate. The BI7DRR reflects the monetary policy stance or stance set by Bank Indonesia and announced to the public. Kemu and Ika (2016) states that BI rate functions to manage market liquidity to achieve operational targets of monetary policy. The purpose of the BI7DRR is also to keep the economy stable and control inflation. The benchmark interest rate is very important for a country because it can affect the loan interest rate and benchmarks that trigger the country's economic growth (Ambalau et al., 2019). Hermawan and Wiagustini (2016) found in his research that interest rates have a significant negative effect on the performance of equity funds. Also, Trivanto et al. (2015) found that the $\mathrm{BI}$ rate negatively affects the movement of the rate of return on equity mutual fund which is assessed by net asset value.

\section{Jakarta Composite Index}

Jakarta composite index is an indicator of stock price movements on the Indonesian Stock Exchange/Bursa Efek Indonesia (BEI). This index includes the movement of all common stock prices and preferred shares listed on the Indonesia stock exchange (Khoiri \& Arghawaty, 2020). A study by Paramastri (2015) stated that an index that contains the totality of shares listed on the stock exchange is called the composite stock price index (Jakarta Composite Index). Ulinnuha et al. (2014) found in their research that Jakarta Composite Index is an independent variable that has a dominant effect on net asset value for mixed mutual funds.

Based on the basic theories and past researches which discussed above, this research would enclose the new findings and the hypothesizes are:

$\mathrm{H}_{1}$ : Inflation has a significant effect on the net asset value of sharia mutual fund.

$\mathrm{H}_{2}$ : BITDRR has a significant effect on the net asset value of sharia mutual fund.

$\mathrm{H}_{3}$ : Jakarta Composite Index has a significant effect on the net asset value of the sharia mutual fund.

$\mathrm{H}_{4}$ : Inflation, BI7DRR, and Jakarta Composite Index simultaneously affect the net asset value of the sharia mutual fund.

Published by University of Airlangga.

This is an open access article under the CC BY license (https://creativecommons.org/licenses/by-nc-sa/4.0/) 


\section{RESEARCH METHODS}

The method used in this research is descriptive verificative research with a quantitative approach. According to Priyono (2016), descriptive research means providing a more detailed description of a symptom or phenomenon. The result of descriptive research is usually typology or patterns regarding the phenomenon being discussed. According to Hardani (2020), verification research is a research with the aim of testing the truth of a phenomenon. Reinforced by definition, according to Sugiyono (2019), where the verification approach is a research method that aims to determine the quality relationship between variables through a test through a statistical calculation, the results of evidence show that the hypothesis is rejected or accepted. According to Hardani (2020), quantitative research is a research that is intended to reveal symptoms holistically contextually through data collection from a natural setting by using the researcher as a key instrument, which focuses on measuring and analyzing cause-and-effect relationships between various variables. In conclusion, the method in this research allows to find out the relationship between the variables within the cause-and-effect, also describe the phenomenon, using statistical calculation and measurement. This method is applied to find out the relationship partially and simultaneously from inflation, BI7DRR, and Jakarta Composite Index to net asset value of sharia mutual fund. Based on the hyphothesis and method, the empirical model of this research is:

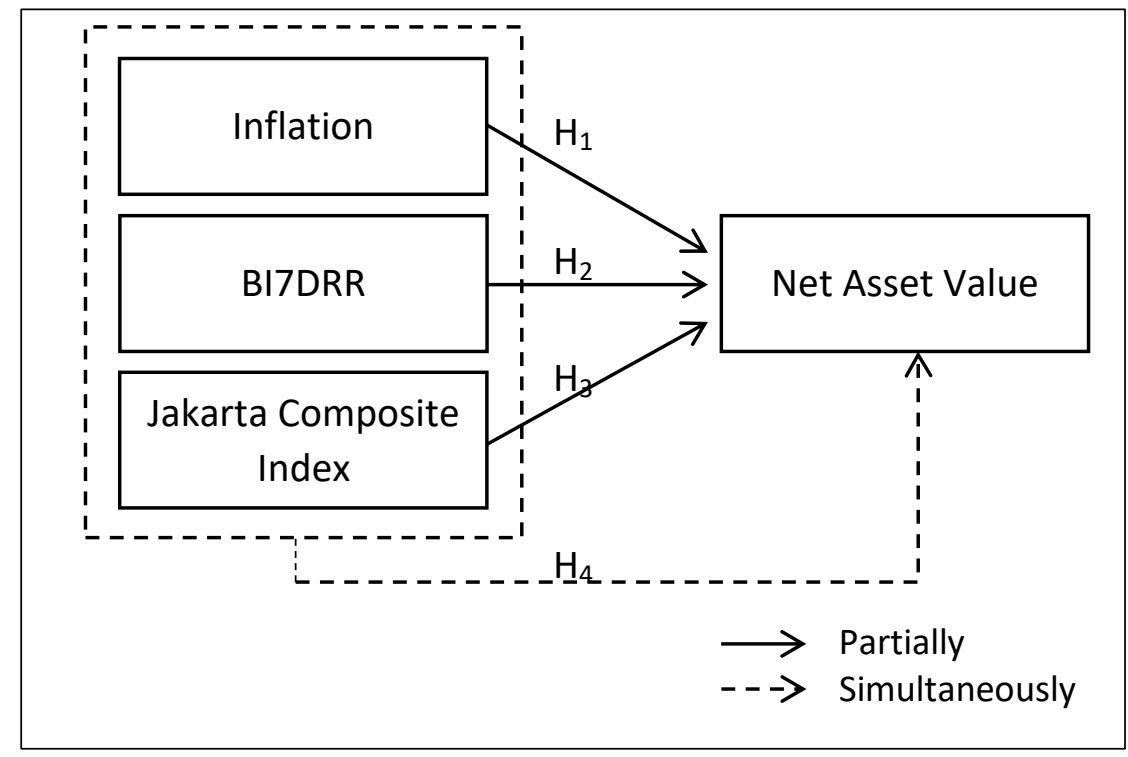

Figure 1. Empirical Model of Research

Source: Data Processed 


\section{Variable Instrument}

The independent variables in this study are inflation $\left(X_{1}\right), B I$ rate $\left(X_{2}\right)$, and Jakarta composite Index $\left(X_{3}\right)$. The dependent variable in this study is the net asset value of sharia mutual fund $(\mathrm{Y})$. The inflation rate and the interest rate value are presented in the form of a percentage obtained from the end-of-month data published on the official website of Bank Indonesia (www.bi.go.id) and BPS (www.bps.go.id). Jakarta Composite Index values are obtained from the official Yahoo Finance website (www.finance.yahoo.com). The net asset value of the mutual funds used is obtained from the official website of the OJK (www.ojk.go.id). All data of variables is time series data per month in 2016-2020. The data processed by using the software SPSS 25 Statistic.

Table 1

Variable Instrument

\begin{tabular}{clc}
\hline No & \multicolumn{1}{c}{ Variable } & Measurement \\
\hline 1 & Inflation & Inflation $=\frac{I H K_{2}-I H K_{1}}{I H K_{1}} \times 100 \%$ \\
2 & BI7DRR & - \\
3 & Jakarta Composite Index & $J C I=\frac{\sum p}{\sum d} \times 100$ \\
4 & $\begin{array}{l}\text { Net Assets Value of Sharia } \\
\text { Mutual Fund }\end{array}$ & NAV $=\frac{\text { (total assets }- \text { total expenses) }}{\text { total participation unit }}$
\end{tabular}

Source: Data Processed

\section{Population and Sample}

The population in this study is the net asset value of all sharia mutual funds in Indonesia in the period of 2016 to 2020 . These years show the growth of sharia mutual fund rapidly, and the latest data makes this research possible to find the updated information and result. The sampling technique used in this study is the sampling purpose. According to Hardani (2020), the main characteristic of this sampling is if the sample members are specially selected based on the research objectives. The sample criteria used for this study are net assets value of active sharia mutual funds and are officially registered with the OJK in the study period 2016 to 2020. The data used in this study are secondary data from various literature such as books, journals, theses, and data sources from official websites. The data collection techniques use literature and documentation.

\section{Data Test and Hypothesis test \\ Ordinary Least Square Test}

According to Duli (2019), the normality test aims to see whether the residual value is normally distributed or not. A good regression model is to have residual values that are normally distributed. The normality test is carried out on the residual value, not individual variables. Normal data observations will provide few extreme 
low and high extreme values and mostly cluster in the middle. Likewise, the mean, mode, and median values are relatively close. This study used the KolmogorovSmirnov non-parametric test with SPSS software. In this test, the data requirement is said to be normal if it has a significant asymptotic value of more than 0.05 .

The multicollinearity test aims to see whether or not there is a high correlation between the independent variables in a multiple linear regression model. If there is a high correlation between the independent variables, then the relationship between the independent and dependent variables will be disturbed (Duli, 2019).

The heteroscedasticity test is to see the presence of variance's inequality (the sum of the squares of all the deviations of individual values to the group mean) from the residuals of one observation to another (Duli, 2019). It also stated that a regression model that meets the requirements is one where the variance of the residuals from one observation to another is fixed or called homoscedasticity. A good model if there is no particular pattern on the chart such as gathering in the middle, narrowing then widening, or preferably widening then narrowing

The autocorrelation test shows whether there is a correlation between a period $t$ and the previous period $(t-1)$. There should be no correlation between observations and previous observational data.

\section{Multiple Linear Regression Analysis}

According to Hardani (2020), multiple regression is a technique used to measure the effect of two or more independent variables on a single dependent variable measured on a ratio scale. Multiple regression analysis in this study aims to determine the impact of inflation, the $\mathrm{BI}$ rate, and the Jakarta Composite Index on the net asset value of sharia mutual funds. The multiple linear regression equation in this study is:

$$
Y=a+b_{1} x_{1}+b_{2} x_{2}+b_{3} x_{3} \ldots . .
$$

This regression also determines the coefficient of determination. Based on Ahmaddien and Syarkani (2019), the coefficient of determination measures the percentage of the influence of all independent variables in the regression model on the dependent variable. The formula for the determinant coefficient is:

$$
K P=r^{2} \times 100 \% \ldots \ldots(2)
$$

Note: $\mathrm{KP}=$ the coefficient of determination; $\mathrm{r}^{2}=$ correlation coefficient value

\section{Hypothesis Test}

This study will explain the results partially (using t-test) and simultaneously (using $\mathrm{F}$ test). The test aims to determine whether or not the effect of the independent variable partially affects the dependent variable. The t-test observing 
the $t^{\prime}$ 's significance value at the level of $0.05(5 \%)$ or comparing the $t_{\text {count }}$ with the

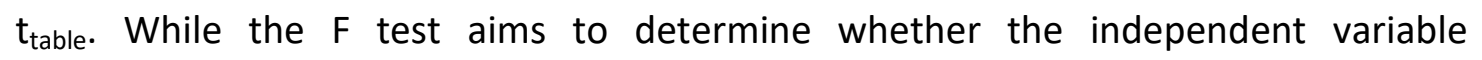
simultaneously affects the dependent variable. The $F$ test is carried out by paying attention to the significant value of the $p$-value at the 0.05 level or comparing the value of $F_{\text {count }}$ with $F_{\text {table. }}$

\section{RESULT AND ANALYSIS}

\section{Descriptive Statistics}

Table 5

Descriptive Statictic

\begin{tabular}{lccccc}
\hline \multicolumn{1}{c}{ Variable } & N & Minimum & Maximum & Mean & Std. Deviation \\
\hline Inflation & 60 & 1.32 & 4.45 & 3.12 & 0.74 \\
BI7DRR & 60 & 3.75 & 7.25 & 5.11 & 0.89 \\
Jakarta Composite Index & 60 & $4,538.93$ & $6,605.63$ & $5,691,73$ & 581.10 \\
Net Asset Value & 60 & $9,061.02$ & $74,367.44$ & $34,265.33$ & $19,682.81$ \\
\hline
\end{tabular}

Source: Data Processed

Based on Table 5, the inflation variable has a minimum data of 1.32 , a maximum data of 4.45 , and a mean of 3.12 with a standard deviation of 0.74 . The B7DRR variable has a minimum data of 3.75 , a maximum data of 7.25 , a mean of 5.11, and a standard deviation of 0.89 . The Jakarta Composite Index variable has a minimum data of 4,538.93, a maximum data of $6,605.63$, and a mean of 5,691.73 with a standard deviation of 581.10. The net assets value of the sharia mutual fund variable has a minimum data of $9,061.02$, a maximum data of $74,367.44$, and a mean of $34,265.33$ with a standard deviation of $19,682.81$.

\section{Ordinary Least Square}

According to Duli (2019), the classical assumption test is a statistical requirement that must be met in a multiple linear regression analysis based on ordinary least square (OLS). The purpose of doing the classical assumption test is to find out whether the linear regression model used is valid, and it can be said that it is the best linear unbiased estimation (BLUE).

The result of the classic assumption test can be described as follows:

1. The normality test shows the asymptotic significance value is $0.200>0.05$, which informs that all variables are normally distributed, so the data is suitable to be used in research.

2. Multicollinearity test shows the VIF value of all the variables $<10$ and tolerance $>0.1$, which means there is no indication of multicollinearity between variables and is suitable for research.

3. The heteroscedasticity test shows the dots in the figure of result spread randomly both up and down the 0 on the $y$-axis. This indicates that no heteroscedasticity in the regression model, so it is suitable to be used in research. 
4. The autocorrelation test shows Watson's Durbin value of 0.289 , which means that the resulting value is in the interval -2 to +2 . It can be concluded that the regression model is free from autocorrelation and suitable to be used in research.

The result of the classic assumption test shows that the required assumptions are met, and this model of regression is BLUE. The results of the classical assumption test are not attached to this journal.

\section{Multiple Linear Regression Analysis}

The multiple linear regression analysis methods is a regression that has one dependent variable and more than one independent variable. Regression aims to determine whether to test the effect of one variable on another. The following are the results of testing multiple linear regression analysis:

Table 6

Multiple Linear Regression Analysis Summary

\begin{tabular}{lccc}
\hline \multicolumn{1}{c}{ Variable } & Regression Coefficient & t-calculate & Sig. \\
\hline Constant & $87,808.736$ & 4.834 & 0.000 \\
INF & $-19,364.267$ & -8.429 & 0.000 \\
BI7DRR & $-3,536.306$ & -1.843 & 0.071 \\
Jakarta Composite Index & 4.383 & 1.645 & 0.106 \\
\hline F calculate & 36.266 \\
R Square & 0660 & \\
\hline
\end{tabular}

Source: Data Processed

Based on the table above the independent variables and control variables on the dependent variable, secondary data obtained by the results of the multiple linear regression model as follows:

$$
Y=87,808-19,364 x_{1}-3,536 x_{2}+4,383 x_{3} \ldots . \text { (3) }
$$

Note: $Y=$ net asset value of sharia mutual fund; $\alpha=$ constant; $X_{1}=$ inflation; $X_{2}=B$ I7DRR; $X_{3}=$ Jakarta Composite Index

The equation shows that a positive $b$ value $(+)$ indicates a unidirectional influence, while a negative $b$ value (-) indicates a non-unidirectional effect. The value of $b_{1}$ and $b_{2}$ are negative $(-)$, which means when inflation and BI7DRR increase, the net asset value of the sharia mutual fund will decrease, vice versa. Meanwhile, the value $b_{3}$ is positive $(+)$, which means when the Jakarta Composite Index increases, the net asset value of the sharia mutual fund will also increase.

Table 6 above also shows the coefficient determination. The $R$ square value is 0.660 or $66 \%$. The result means the net asset value of sharia mutual fund can be influenced by the variables in this research as much as about $66 \%$. In comparison, the remaining $34 \%$ factor of influence is other variables outside of this study.

\section{Hypothesis Testing}


The t-test determines how far the influence of one independent variable is in explaining the dependent variables individually, testing the t-value by comparing $\mathrm{t}$ calculate with the t-table and see the significance. The t-table value for this regression model is 2.003 . In Table 6, for the inflation variable, it has a t-calculate $8.429>$ t-table. It has a significance of $0.00<0.05$ probability. This result concludes that $H_{1}$ is accepted, meaning that inflation $\left(X_{1}\right)$ affects the net assets value of sharia mutual funds. As for the BI7DRR variable, it has a t-calculate $1.843>$ t-table. It has a significance of $0.71>0.05$ probability. It can be concluded that $\mathrm{H}_{2}$ is rejected, meaning that there is no effect of BI7DRR $\left(X_{2}\right)$ on the net assets value of sharia mutual funds. For the Jakarta Composite Index variable, it has a t-calculate $1.645>\mathrm{t}$ table, and has a significance of $0.106>0.05$ probability. This result concludes that $\mathrm{H}_{3}$ is rejected, meaning that there is no effect of the Jakarta Composite Index $\left(X_{3}\right)$ on the net assets value of sharia mutual funds.

The $F$ test is performed to show all independent variables in the form of inflation and the BI7DRR has a significant effect on the dependent variable in the form of net asset value of sharia mutual fund simultaneously. This study used a significance of 0.05 (5\%). Test F test comparing the F-count with the F-table or seeing the significance. The F-table value for this regression model is 2.77. Based on Table 6, F-calculate is $36.266>$ F-table 2.77, so it can be concluded that $\mathrm{H}_{4}$ is accepted or, in the other word, inflation $\left(X_{1}\right)$, BI7DRR $\left(X_{2}\right)$, and Jakarta Composite Index $\left(X_{3}\right)$ simultaneously affect the net asset value of sharia mutual fund $(Y)$.

\section{Analysis of Result}

Based on the results of the tests, inflation on the net asset value of sharia mutual fund has a significant and negative effect. The result explains that any increase or decrease in the inflation rate will also cause a movement in the value of the net asset value of the sharia mutual fund. If inflation increases, the net asset value of the sharia mutual fund will decrease. This effect can indicate the economic behavior of the community. As the prices of goods increase and needs become expensive, the community will reduce their investment in sharia mutual funds because they need more money to fulfill the needs and consumption. They also tend to save money on themselves to get ready for the possibility of higher inflation in forward. This result and analysis are in line with the study of Azkiyah (2017), which stated that inflation with the increase in prices continuously makes investors more aware in investing their fund, so it causes the decrease of net asset value. Inflation can also affect the company. The statement is stated by Bakrie (2019) that inflation will cause the prices to increase and the turnover of a company to decrease. This phenomenon will reduce the company's income. The low income of the company will make investors less interested in investing in their fund. A study by Trivanto et al. (2015) also mentioned that inflation makes people's consumption lower and 
decreases a company's profit. Inflation also reduces the demand for company's shares. As a result, it affects low-price shares and returns, so the net asset value of mutual funds with share/stock portfolios will decrease.

BI7DRR in the results of this study indicates that it has a negative and insignificant effect on the net asset value of sharia mutual funds. This negative effect means that when the BI7DRR increases, the net asset value of sharia mutual funds will decrease. Conversely, if the BI7DRR decreases, the net asset value of sharia mutual funds will increase. However, this insignificant effect reflects that the fluctuation of the BI7DRR value does not have a major impact on the movement of the net asset value of sharia mutual funds. This can describe the investment pattern of investors who do not make the BI7DRR a strong consideration in managing their investment funds in sharia mutual funds. The result in this study is consistent with research by Nandari (2017). Partially, the BI7DRR (or BI rate at the moment) had a negative and insignificant effect on the net asset value of sharia mutual funds. The author argued that the negative impact of the $\mathrm{BI}$ rate affects the company. When the $\mathrm{BI}$ rate increases, the company must reduce the loan capital in order not to pay relatively high interest returns. The payment causes company's performance to decline. Hence the value of shares in the market drops, company performance goes low, and the net asset value in the capital market also decreases. This insignificant effect is caused by the sharia mutual funds mechanism that invests funds in sharia investment products or companies which are met the requirements of sharia principle; one of them is not benchmarking interest rate and has minimum debt. So the increase of interest rate will not much affect the company return and not significantly affect the net asset value. Another result for negative effect from the $\mathrm{BI}$ rate on net asset value also exists in the study of Azkiyah (2017). The study stated that the effect of $\mathrm{BI}$ rate happens on the investors. When the $\mathrm{BI}$ rate increases, investors tend to invest their funds in bank products such as saving and deposit to gain more profit with high interest rate. So they will decrease the investment in mutual funds and increase investment in bank products. As a result, it will affect the net asset value of the mutual funds to be declined.

Jakarta Composite Index is stated to have a positive and insignificant effect on the movement of the net asset value of sharia mutual fund. Hence, the $\mathrm{H}_{3}$, where the Jakarta Composite Index has a significant impact on the net asset value of sharia mutual fund is rejected. The positive coefficient indicates that if the Jakarta Composite Index value increases, the net asset value of sharia mutual funds will also increase. The relationship is assumed to occur considering several mutual fund mechanisms that invest their funds into stock instruments. An increase in Jakarta Composite Index shows that income from the portfolio will also increase, thereby attracting investor's interest to invest in mutual funds with a composition of stock portfolios. The result is in line with the study of Malik (2017), where the expectation of obtaining investment returns in the sharia capital market motivates investors to 
consider purchasing investment products in the sharia capital market. However, the results of this study indicate that the effect is not significant, so it can be assumed that the increase or decrease in the Jakarta Composite Index does not affect the decision of investors to invest in sharia mutual funds. The result of this study is also in line with study of Muslim (2018). It stated that the Jakarta Composite Index value has no significant effect on the net asset value of sharia mutual funds. In his research, Muslim (2018) also agreed that investors do not pay attention to the fluctuation of the Jakarta Composite Index value as one of the considerations for investors in making decisions to place their funds in sharia mutual funds.

The test results in this study also show that inflation, BI7DRR, and the Jakarta Composite Index simultaneously affect the net asset value of the sharia mutual funds. These three variables influence the movement of net asset value of sharia mutual fund by $66 \%$ based on simultaneous tests carried out. This indicates that an increase or decrease in the value of inflation and the BI7DRR simultaneously affect the movement of the net asset value of the sharia mutual fund.

\section{CONCLUSION}

The result analysis finds that there is only one from three hypotheses that is proven. Inflation has a significant effect on the net asset value of sharia mutual funds negatively. The interest rate and Jakarta Composite Index have no significant effect on the net asset value of the sharia mutual fund. On the side, inflation, interest rate, and Jakarta Composite Index simultaneously and significantly affect the net asset value of sharia mutual funds. This result can represent the economy habitual of public in responding the situation of the economy at a particular moment and how it can affect the value of the investment.

The results of this research can be an education for the public about the net asset value of sharia mutual fund, and the factor affects on it. Perhaps, it will increase the opportunity for the investor to gain higher profit and avoid loss with the knowledge of the right situation of the economy. Also, this research can be a reference for the investment manager of sharia mutual fund in responding to the economic crisis to improve the performance of managing the net asset value.

\section{ACKNOWLEDGMENT}

The authors would love to express grateful to Allah SWT for His bless and mercy so this study could successfully held. The authors also deeply indebted to the beloved family and colleagues for all the warm support and pray. Sincerest gratitude goes to the editorial board of JEBIS who have patiently assisted in the improvement of this study. A great thanks will always be sent to the readers who have appreciated this study by reading this work and giving suggestion.

Published by University of Airlangga.

This is an open access article under the CC BY license (https://creativecommons.org/licenses/by-nc-sa/4.0/) 


\section{REFERENCES}

Ahmaddien, I., \& Syarkani, Y. (2019). Statistika Terapan dengan Sistem SPSS (E. Warsidi (ed.); 1st ed.). ITB Press.

Ambalau, P. D. V., Kumaat, R. J., \& Mendeij, D. (2019). Analisis Pengaruh Jumlah Uang Beredar, Kurs, dan Sibor terhadap Suku Bunga Pinjaman Bank Umum melalui Suku Bunga Acuan BI Periode 2016:Mo9-2018:M12. Jurnal Berkala Ilmiah Efisiensi, 19(3), 23-33.

https://ejournal.unsrat.ac.id/index.php/jbie/article/view/25271

Azkiyah, I. S. (2017). Pengaruh Bank Indonesia (BI) Rate, Inflasi, dan Nilai Tukar Rupiah (Kurs) terhadap Nilai Aktiva Bersih (Nab) Reksadana Campuran Syariah Periode 2014-2016 [UIN Syarif Hidayatullah Jakarta].

https://repository.uinjkt.ac.id/dspace/handle/123456789/41180

Badan Pusat Statistik. (2021). Inflasi.

Bakrie, M. A. (2019). Pengaruh Inflasi dan Indeks Harga Saham Gabungan terhadap Net Asset Value Reksadana Syariah dengan Nilai Tukar Ruiah sebagai Variabel Moderating. Universitas Islam Negeri Alauddin Makassar.

Bank Indonesia. (2020). Inflasi.

Duli, N. (2019). Metodologi Penelitian Kuantitatif. Deepublish Publishe.

Febriani, S. (2014). Analisis Investasi dalam Instrumen Reksadana pada Dana Pensiun (Studi pada Dana Pensiun Pupuk Kalimantan Timur Tahun 2009-2012). Jurnal Administrasi Bisnis, 8(1), 1-8.

http://administrasibisnis.studentjournal.ub.ac.id/index.php/jab/article/view/ 349

Hardani, H. (2020). Metode Penelitian Kualitatif dan Kuantitatif. Pustaka Ilmu.

Hermawan, D., \& Wiagustini, N. L. P. (2016). Pengaruh Inflasi, Suku Bunga, Ukuran Reksa Dana, Dan Umur Reksa Dana Terhadap Kinerja Reksa Dana. E-Jurnal Manajemen Universitas Udayana, 5(5), 3106-3133.

https://ojs.unud.ac.id/index.php/Manajemen/article/view/20110

Kasmir, K. (2014). Bank Dan Lembaga Keuangan Lainnya. Raja Grafindo Persada.

Kasyfurrohman, A. (2012). Analisis Pengaruh Variabel Makroekonomi terhadap Reksadana Syariah di Indonesia [Institut Pertanian Bogor]. https://adoc.pub/analisis-pengaruh-variabel-makroekonomi-terhadapreksadana-s.html

Kemu, S. Z., \& Ika, S. (2016). Transmisi BI Rate sebagai Instrumen untuk Mencapai Sasaran Kebijakan Moneter. Kajian Ekonomi Keuangan, 20(3), 261-284. https://doi.org/https://doi.org/10.31685/kek.v20i3.208

Khaddafi, M., Siregar, S., Noch, M. Y., Nurlaila, N., Harmain, H., \& Sumartono, S. (2017). Akuntansi Syariah: Meletakkan Nilai-Nilai Syariah Islam dalam IImu Akuntansi (A. Ikhsan (ed.)). Penerbit Madenatera.

Khoiri, H. A., \& Arghawaty, E. (2020). Menganalisis Nilai IHSG Beserta Faktor-Faktor yang Mempengaruhi di Era Pandemik COVID-19. Jurnal Riset Akuntansi Dan Keuangan Dewantara (JAD), 3(2), 110-121. https://doi.org/10.26533/jad.v3i2.677

Lailiyah, E. H., Suhadak, S., \& Sulasmiyati, S. (2016). Analisis Perbandingan Kinerja Reksadana Syariah dan Reksadana Konvensional (Studi pada Reksadana yang Terdaftar di Otoritas Jasa Keuangan Periode 2012-2016). Jurnal Administrasi Bisnis, 35(2), 114-121. 
http://administrasibisnis.studentjournal.ub.ac.id/index.php/jab/article/view/ 1376

Malik, A. D. (2017). Analisa Faktor-Faktor yang Mempengaruhi Minat Masyarakat Berinvestasi di Pasar Modal Syariah Melalui Bursa Galeri Investasi UISI. Jurnal Ekonomi Dan Bisnis Islam (Journal of Islamic Economics and Business), 3(1), 61-84. https://doi.org/10.20473/jebis.v3i1.4693

Mastura, A., Nuringwahyu, S., \& Zunaida, D. (2020). Pengaruh Motivasi Investasi, Pengetahuan Investasi Dan Teknologi Informasi Terhadap Minat Berinvestasi di Pasar Modal (Studi pada Mahasiswa FIA dan FEB UNISMA yang Sudah Menempuh Mata Kuliah Mengenai Investasi). Jurnal Ilmu Administrasi Niaga/Bisnis (JIAGABI), 9(1), 64-75.

http://www.riset.unisma.ac.id/index.php/jiagabi/article/view/6125

Mulawarman, A. D., Triyuwono, I., Irianto, G., \& Ludigdo, U. (2011). Menuju Teori Akuntansi Syariah Baru. Jurnal Ekonomi Dan Keuangan Islam, 1(1), 61-78. https://journal.uii.ac.id/JEKI/article/view/8748

Muslim, A. (2018). Pengaruh Domestik Bruto, Sertifikat Bank Syariah, dan Indeks Harga Saham Gabungan Terhadap Nilai AKtiva Bersih Reksdana Syariah di Indonesia [Institut Agama Islam Negeri Tulungagung]. http://repo.iaintulungagung.ac.id/9374/

Nandari, H. D. R. A. U. (2017). Pengaruh Inflasi, Kurs, dan BI Rate terhadap Nilai Aktiva Bersih (NAB) Reksadana Syariah di Indonesia (Periode 2010-2016) [IAIN Tulungagung]. http://repo.iain-tulungagung.ac.id/5201/

Nisa, A. (2017). Pengaruh Pemahaman Investasi, Modal Minimal Investasi, dan Motivasi terhadap Minat Mahasiswa Berinvestasi di Pasar Modal. Jurnal Penelitian Teori Dan Terapan Akuntansi (PETA), 2(2), 22-35. https://doi.org/10.51289/peta.v2i2.309

Paramastri, K. (2015). Analisis Determinan Indeks Harga Saham Gabungan (Composite Index) di Bursa Efek Indonesia Periode 2011-2013. Universitas Negeri Yogyakarta.

Prasetyo, D., \& Widiyanto, W. (2019). Pengaruh Inflasi, Nilai Tukar Rupiah, Suku Bunga Bank Indonesia dan Harga Emas terhadap Nilai Aktiva Bersih Reksadana Syariah. Prosiding Konferensi IImiah Mahasiswa Unissula (KIMU) Klaster Ekonomi, 133-153. http://Ippmunissula.com/jurnal.unissula.ac.id/index.php/kimue/article/view/8720 Priyono, P. (2016). Metode Penelitian Kuantitatif. Zifatama Publishing.

Qomariah, N., Sari, M. I., \& Budiarti, D. A. (2016). Perbandingan Kinerja Rekasadana Syariah dan Reksadana Konvensional (pada Reksadana Saham dan Reksadana Pendapatan Tetap yang Terdaftar di BEI Periode 2010-2014). Jurnal Keuangan Dan Perbankan, 20(3), 417-427. https://doi.org/10.26905/jkdp.v20i3.273

Rachman, A., \& Mawardi, I. (2015). Pengaruh Inflasi, Nilai Tukar Rupiah, BI Rate Terhadap Net Asset Value Reksa Dana Saham Syariah. Jurnal Ekonomi Syariah Teori Dan Terapan, 2(12), 986-1001. https://doi.org/10.20473/vol2iss201512pp986-1001

Saputra, D. (2018). Pengaruh Manfaat, Modal, Motivasi, dan Edukasi terhadap Minat Berinvestasi di Pasar Modal. Future Jurnal Manajemen Dan Akuntansi, 5(2), 178-190. https://www.neliti.com/publications/266016/pengaruh-manfaat- 
modal-motivasi-dan-edukasi-terhadap-minat-dalam-berinvestasi-di

Sugiyono, S. (2019). Metode Penelitian Kuantitatif, Kualitatif, dan R\&D (2nd ed.). Alfabeta.

Trivanto, A., Najmudin, N., \& Sulistyandari, S. (2015). Analisis Pengaruh Suku Bunga Sertifikat Bank Indonesia, Tingkat Inflasi, Indeks Harga Saham Gabungan (IHSG), Indeks Bursa Asing Dan Nilai Tukar Rupiah Terhadap Tingkat Pengembalian Reksa Dana Saham Di Indonesia. Journal \& Proceeding Fakultas Ekonomi Dan Bisnis UNSOED, 5(1), 1-17. http://www.jp.feb.unsoed.ac.id/index.php/sca-1/article/view/759

Ulinnuha, A., Fadah, I., \& Farida, L. (2014). Pengaruh Indeks Harga Saham Gabungan, Nilai Tukar Rupiah dan Sertifikat Bank Indonesia Terhadap Nilai Aktiva Bersih Reksadana Campuran Pada PT. Manulife Aset Manajemen Indonesia. Student Research Article. https://repository.unej.ac.id/handle/123456789/64320

Wiradiyasa, I. (2016). Analisis Pengaruh Inflasi, Suku Bunga SBI, dan Kurs Terhadap Kinerja Reksadana Syariah di Indonesia (Periode Waktu Tahun 2010-2014). Jurnal IImiah Mahasiswa FEB Universitas Brawijaya, 4(1). https://jimfeb.ub.ac.id/index.php/jimfeb/article/view/2643

Wirman, W. (2020). Pengaruh Nilai Tukar (Kurs), Jumlah Uang Beredar dan Inflasi terhadap Nilai Aktiva Bersih Reksa Dana Syariah di Indonesia tahun 20152019. Accounthink: Journal of Accounting and Finance, 5(2), 239-258. https://journal.unsika.ac.id/index.php/accounthink/article/view/4311

Yazir, A. G., \& Suhardi, S. (2014). Analisis Perbandingan Risiko dan Tingkat Pengembalian Reksadana Syariah dan Reksadana Konvensional (Comparison of Risk and Level of Returns of Conventional Sharia and Consequences). Journal of Accounting Fakultas Ekonomi Universitas Bangka Belitung, 1(1), 118. https://doi.org/10.2139/ssrn.3369311 